\title{
Anatomy of the abdominal aorta in the hoary fox (Lycalopex vetulus, Lund, 1842)
}

\section{Anatomia da aorta abdominal em raposa-do-campo (Lycalopex vetulus, Lund, 1842)}

\author{
Dara Rúbia Souza SILVA'; Mônica Duarte da SILVA ${ }^{1}$; Marcos Paulo Batista de ASSUNÇÃO' ${ }^{1}$; Eduardo Paul \\ CHACUR $^{1}$; Daniela Cristina de Oliveira SILVA ${ }^{2}$; Roseâmely Angélica de Carvalho BARROS ${ }^{1}$; Zenon SILVA ${ }^{1}$ \\ ${ }^{1}$ Universidade Federal de Goiás, Regional Catalão, Instituto de Biotecnologia, Departamento de Ciências Biológicas, Catalão - GO, Brazil \\ ${ }^{2}$ Universidade Federal de Uberlândia, Instituto de Ciências Biomédicas, Departamento de Anatomia Humana, Uberlândia - MG, Brazil
}

\begin{abstract}
The hoary fox (Lycalopex vetulus, Lund, 1842) is the smallest Brazilian canid, whose weight varies between 2 and $4 \mathrm{~kg}$, has a slender body, a small head, and a short and blackened snout. Despite being considered an endemic species, little is known about the hoary fox as it is one of the seven less studied canids in the world. Thus, this study aimed to describe the anatomy of the abdominal aorta artery of the hoary fox and to compare it with the pre-established literature data in domestic canids. For this purpose, we used two adult hoary foxes without definite age. We collected the corpses of these animals along roadsides of Catalão-GO, being later fixed and conserved in a $10 \%$ formalin solution. The results showed that the abdominal aorta in hoary fox is at the ventral face of the lumbar region vertebral bodies, being slightly displaced to the left of the median plane. The first branch is visceral, named celiac artery, followed by a paired parietal branch: the phrenic abdominal arteries. The third and fourth branches are the cranial mesenteric arteries and the right and left are the renal arteries, respectively. The posterior branches of the renal arteries are equally visceral, paired, being called testicular arteries. Distal to the latter, both the caudal mesenteric artery and deep circumflex iliac arteries originate. Finally, two large external iliac arteries and its terminal branches composed of internal iliac arteries and the median sacral artery originate. In addition, five pairs of lumbar arteries originate alongside the abdominal segment of the aorta. Considering these findings, it is possible to conclude that despite the hoary fox being a wild animal, the anatomy of its abdominal aorta is very similar to that of domestic canids.
\end{abstract}

Keywords: Abdominal aorta artery. Anatomy. Angiology. Cerrado canid. Hoary fox.

\section{Resumo}

A raposa-do-campo (Lycalopex vetulus, Lund, 1842) é o menor canídeo brasileiro, cujo peso varia entre 2 e 4 quilos, possui corpo esguio, a cabeça é pequena, focinho curto e enegrecido. Considerada uma espécie endêmica, pouco se sabe a seu respeito, e é um dos sete canídeos menos estudados no mundo. Assim, o presente estudo teve o objetivo de descrever a anatomia da parte abdominal da artéria aorta em raposa-do-campo e comparar com dados literários pré-estabelecidos de canídeos domésticos. Para a realização deste estudo foram utilizados dois exemplares de raposa-do-campo, adultos, sem idade definida. Os cadáveres dos animais foram recolhidos às margens de rodovias no entorno da Catalão-Goiás, fixados em solução aquosa de formol a $10 \%$ e conservados na mesma solução. Os resultados mostraram que a aorta abdominal da raposa-do-campo está localizada sobre a face ventral dos corpos vertebrais da região lombar, levemente deslocada para a esquerda do plano mediano. O primeiro ramo é visceral, denominado artéria celíaca, seguido por um ramo parietal, pareado, as artérias frênico-abdominais. O terceiro e quarto ramos são a artéria mesentérica caudal e as artérias renais direita e esquerda, respectivamente. Os ramos posteriores das artérias renais são igualmente viscerais, pareados, denominados artérias testiculares. Distal à essas últimas, originam-se a artéria mesentérica caudal e as artérias circunflexas ilíacas profundas. Finalmente surgem duas grandes artérias ilíacas externas e os ramos terminais compostos pelas artérias ilíacas internas e artéria sacral mediana. Ao longo do trajeto da aorta abdominal, cinco pares de artérias lombares se originam da face dorsal. Considerando esses achados, pode ser concluído que a anatomia da aorta abdominal da raposa-do-campo é muito similar àquela de canídeos domésticos, embora ela seja um animal silvestre.

Palavras-chave: Artéria aorta abdominal. Anatomia. Angiologia. Canídeos do cerrado. Raposa-do-campo. 
Correspondence to:

Dr. Zenon Silva

Universidade Federal de Goiás, Regional Catalão, Instituto de Biotecnologia, Departamento de Ciências Biológicas

Av. Dr. Lamartine Pinto de Avelar, 1120 - Setor Universitário

CEP 75704-020, Catalão, GO, Brazil

e-mail: zenon_silva@ufg.br

Submited: $24 / 05 / 2018$

Approved: 06/11/2018

\section{Introduction}

The Comparative Animal Anatomy is a field of the Anatomy that studies the morphological organization of different taxonomic groups and compares its morphofunctional interspecific relations. Unlike Human Anatomy and the Anatomy of Domestic Animals, which seek to study the elements that comprise the body without a comparative bias, Comparative Anatomy not only aims to study the structural organization of the body, but also focuses on the association between shape and the animal's way of life and its inherent adaptations to the biome. Hence, more accurate studies of comparative approach on the body structural organization are valuable as they facilitate the understanding of physiological and evolutionary processes that may eventually be associated with the body shape or the anatomical structure, including the inherent adaptations to the alimentary and reproductive habits (OLIVEIRA et al., 2004).

The hoary fox (Lycalopex vetulus, Lund, 1842) is the only Brazilian canid species endemic to the Cerrado, being most commonly found in the central and south region of the country, a biome under high anthropogenic pressure and with less than $20 \%$ of its original area that is still of primitive state, reason why some consider many components of its fauna as vulnerable. For being an endemic species, the limits of its original geographic distribution only approach Cerrado, with areas of savannah vegetation. However, one can find such species in transition zones, including open Pantanal habitats, mosaics of fields and xerophytic vegetation, even though there may still be regions where it has not been registered (DALPONTE, 2009).

The hoary fox is a graceful animal with a small head, thin body and members (Figure 1). The coat of the upper body is pale gray and the ventral parts are yellowish, except for the ventral parts of the neck that are white (DE PAULACOUTO, 1950). Its trademark is on its long and bulky tail with a dark spot at its base and another at the end (LEMOS et al., 2013). In both genders, the general color is yellowish-gray, although males may have a band of black hairs extending from the nape of the neck to the tail end (DALPONTE, 2009). The hoary fox is the smallest Brazilian canid, whose weight can reach up to $4 \mathrm{~kg}$, sometimes being higher than that. It has nocturnal habits and can be found in fields of Cerrado in states such as Mato Grosso, Goiás, Minas Gerais and São Paulo. Despite the hoary fox being considered an endemic species, very little is known about it, and it is one of the seven less studied canids in the world (LEMOS et al., 2013). In this context, although the number of specimens has apparently increased in recent times, as specimens usually found alongside roads, it is still part of the red book of Brazilian fauna endangered to be extinct, justifying the importance of studies on its biology (MACHADO et al., 2008). On the other hand, studies of this order can contribute with clinical-surgical procedures and organization of protection and conservation programs.

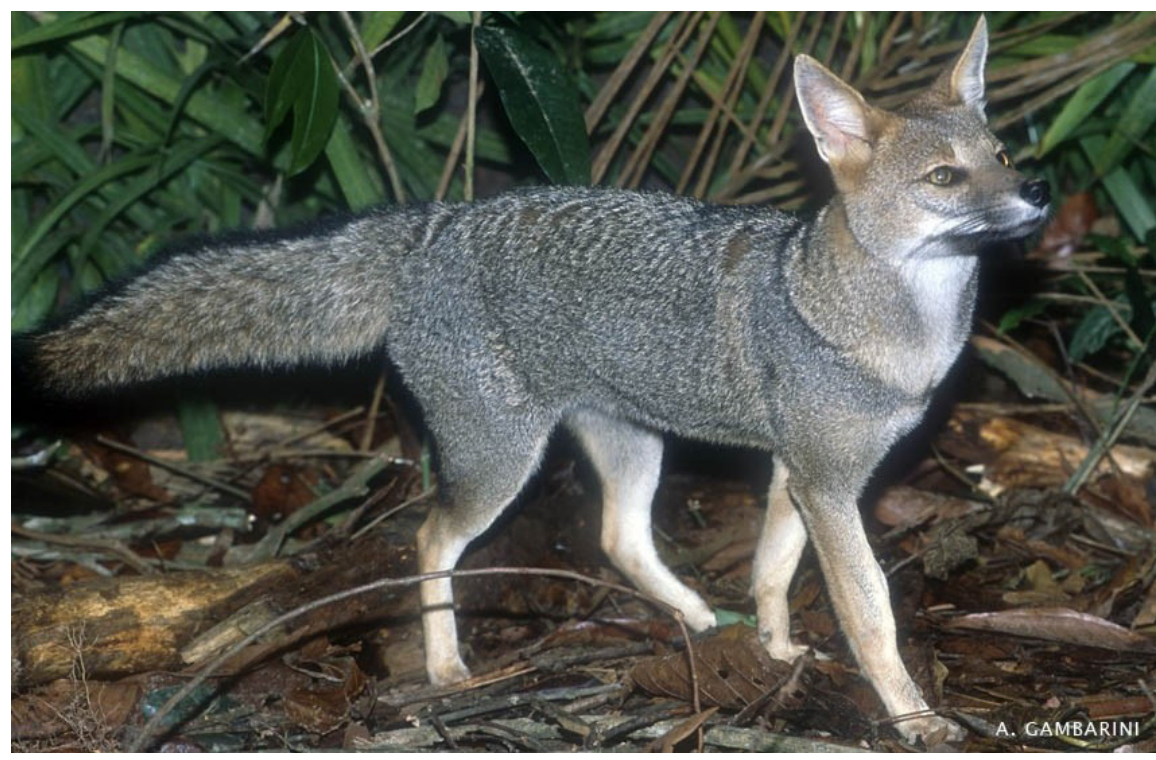

Figure 1 - Female hoary fox (Lycalopex vetulus) specimen

Photo source: http://euquerobiologia.blogspot.com/2011/10/raposa-do-campo-lycalopex-vetulus.html 
This study aimed to describe the anatomy of the abdominal part of the aorta artery in the hoary fox (Lycalopex vetulus), comparing it with the pre-established literature data on domestic canids. It is worth to highlight there is no detailed literature data on the anatomical description of the abdominal aorta in wild Brazilian canids.

\section{Materials and Methods}

To develop this study, two male specimens of adult hoary fox (Lycalopex vetulus) of indefinite ages were used. The corpses of these animals were collected alongside roads of Catalão-GO, under authorization SISBIO nº 37072-2. The animals were sent to the Anatomy Laboratory, where Arte Cola Latex of red color was injected in their arterial system to better visualize the proposed arteries, a procedure based on Rodrigues (2005). Subsequently, the animals were fixed and conserved in a $10 \%$ formalin solution.

The preparation of the anatomical pieces was performed according to the technical procedures routine in Macroscopic Anatomy (RODRIGUES, 2005). Briefly, after shaving and cleaning the anterolateral region of the abdomen, an incision was made along the alba line, starting up in the xiphoid process and continuing up to the cranial end of the pubic symphysis. Two lateral incisions were performed, one of them accompanying the costal margin of each side and the other one in the inguinal region at the level of the inguinal ligament. The abdominal wall was laterally bent until the abdominal viscera were exposed. The intestine was removed, exposing the dorsal wall of the abdomen. From then on, with the aid of an anatomical forceps $(16 \mathrm{~cm})$, tissues (including the adipose one) were removed until exposing the aorta artery and its branches.

The photographic documentation was made using a Sony Cyber Shot 7.2 mp digital camera. The nomenclature adopted for the description of the results followed the Nomina Anatomica Veterinaria (ICVGAN, 2017). This study was developed with the approval of the Ethics Committee of the Institution (CEUA/UFU n ${ }^{\circ}$ 067/12).

\section{Results}

In the hoary fox, the abdominal aorta gives continuation to the descending aorta, after its crossing with the diaphragm. It is located at the ventral face of the lumbar region vertebral bodies. At first, it is closely linked to the caudal vena cava in the median sagittal plane, being slightly shifted to the left (Figure 2).
In this animal, the first branch of the abdominal segment of the aorta is a visceral one, namely the celiac artery, which is a short and unique arterial trunk originated from the ventral face of the aorta located between diaphragmatic pillars. Not far from its original point, the celiac artery divides itself into four main branches (the hepatic, the left gastric, the dorsal gastric and the lienal arteries) (Figure 2).

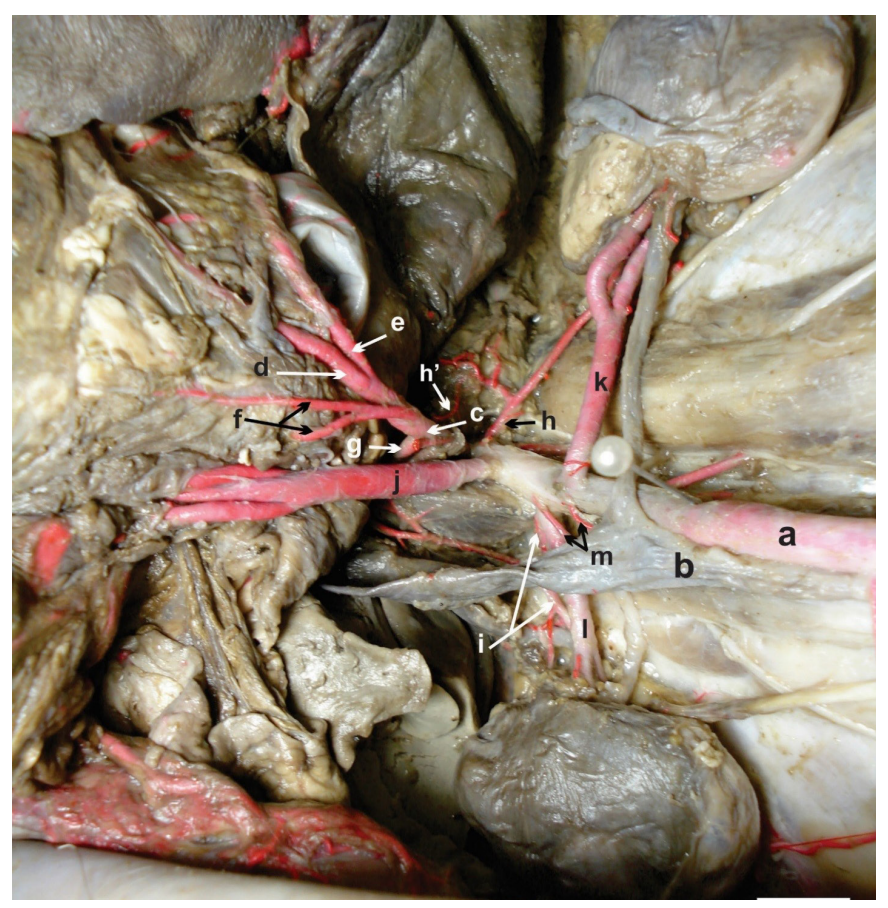

Figure 2 - Ventral view of the cranial part of the abdominal cavity of the hoary fox. (a) abdominal aorta artery, (b) caudal vena cava, (c) celiac artery, (d) hepatic artery, (e) left gastric artery, (f) splenic artery, $(g)$ dorsal gastric artery, $(h)$ left phrenic-abdominal artery, ( $h$ ') accessory left caudal phrenic artery, (i) right phrenic-abdominal artery, (j) cranial mesenteric artery, $(k)$ left renal artery, $(l)$ right renal artery, $(m)$ small mesenteric arteries. Scale bar: $2 \mathrm{~cm}$

The second branch of the abdominal aorta is parietal and paired, being called right and left phrenicabdominal arteries (Figure 2). These arteries always originate separately; however, in both antimeres, they branched into the caudal phrenic and adrenal arteries (Figure 3), the latter branching into the dorsal abdominal wall. In the right antimere, the phrenicabdominal artery originates at the right side of the aorta, after the origin of the cranial mesenteric artery, showing a branching pattern similar to that of the left one (Figures 2 and 3).

The third and largest branch of the abdominal part of the aorta is the cranial mesenteric artery originated from the ventral face of the aorta, continuing through ventrocaudal margins and penetrating between mesentery blades (Figure 2). 


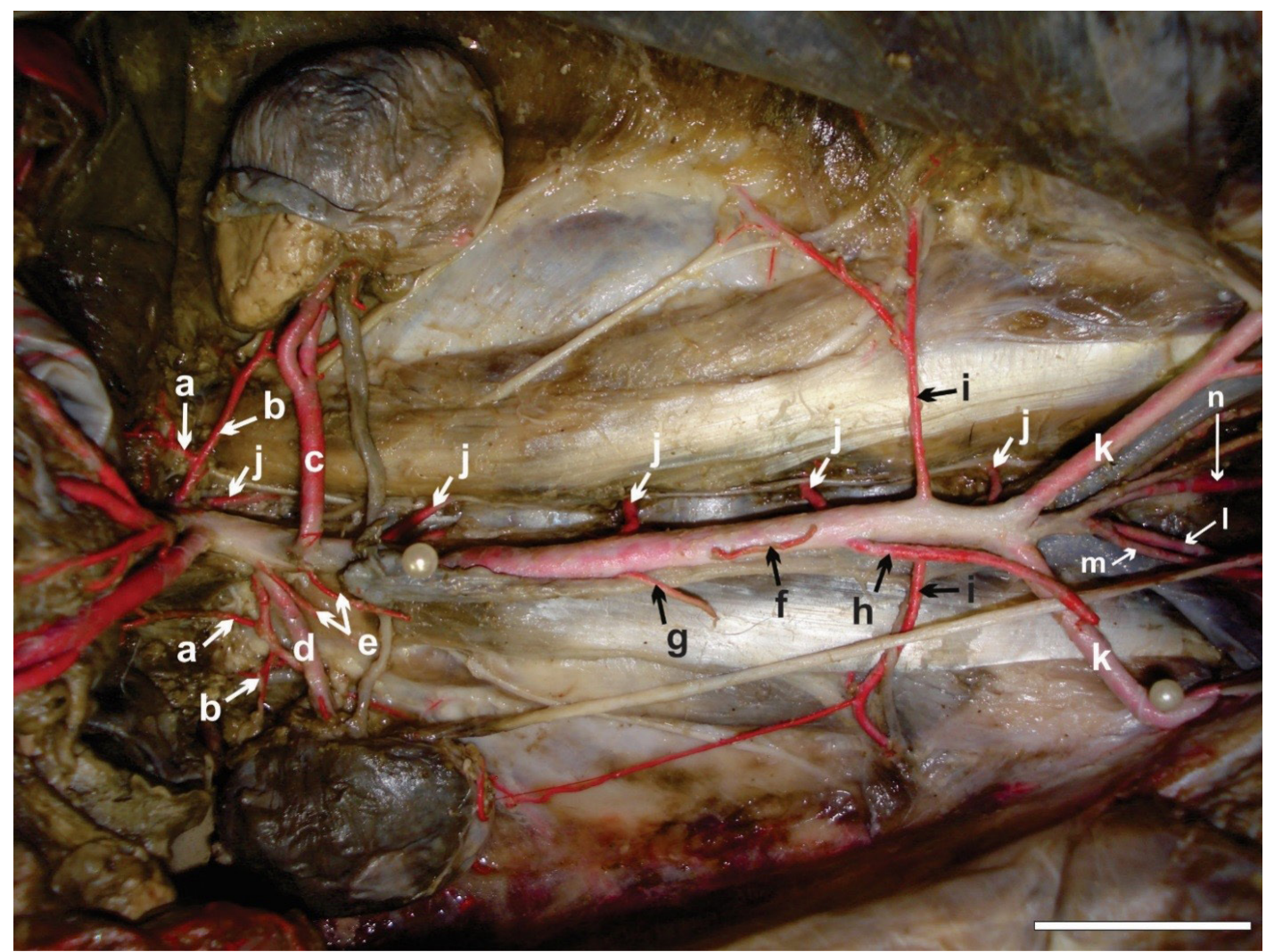

Figure 3 - Ventral view of the abdominal cavity of the hoary fox. (a) caudal phrenic artery, (b) adrenal arteries, (c) left renal artery, $(d)$ right renal artery, (e) small mesenteric arteries, $(f)$ left testicular artery, $(g)$ right testicular artery, $(h)$ caudal mesenteric artery, $(i)$ deep iliac circumflex arteries, $(j)$ lumbar arteries, $(k)$ external iliac arteries, $(l)$ right internal iliac artery, $(m)$ right obturator artery, $(n)$ sacral median artery. Scale bar: $3 \mathrm{~cm}$

The fourth branch of the abdominal aorta in the hoary fox is the renal artery, divided into left and right, and of asymmetric origin at the lateral side of the aorta, as the left renal artery originates caudally in relation to the right renal artery. Two small mesenteric arteries originate from the ventral face of the abdominal aorta at the same origin level of renal arteries (Figures 2 and 3), being distributed into the mesentery.

The posterior branches of the renal arteries are equally visceral, paired, and called testicular arteries. The testicular arteries originate from the ventro-lateral face of the aorta; the origin of the right testicular artery is displaced cranially in relation to the left one (Figure 3).

Distally to the origin point of the testicular arteries is the small caudal mesenteric artery, which is originated from the ventral face of the aorta, penetrating between mesocolon blades into the descending colon and sigmoid colon (Figure 3). Caudally to the caudal mesenteric artery, there are the deep circumflex iliac arteries, one at each side, originated laterally and directed to the flank region (Figure 3).

Five pairs of lumbar arteries originate along the abdominal segment of the aorta; the first pair is located cranially to the renal arteries while the other four are more caudally located ; all originate individually from the abdominal aorta (Figure 3).

The final segment of the abdominal aorta is the external iliac arteries, which follows caudally and laterally towards the thigh, entering the vascular gap as the femoral artery (Figure 3).

After external iliac arteries origination, the diameter of the abdominal aorta in hoary fox reduces significantly, continuing caudally for a short distance and branching it into five terminal branches (two internal iliac arteries, two obturator arteries and one median sacral artery), which are much smaller than the external iliac arteries (Figure 3).

\section{Discussion}

Studies and discussions on the Comparative Anatomy of wild animals have been taking place among researchers of morphofunctional relationships between similar anatomical structures associated with the process of adaptation to the environment, survival and reproduction.

We compared the results here presented by compiling literature data on domestic canids, considering these animal groups are very close in the phylogenetic scale and 
no specific data on the anatomy of the abdominal aorta and its branches in other canids have been identified.

The origin and location of the abdominal aorta of hoary fox is similar to that described for domestic dogs, accompanying the roof of the abdomen, closely to the caudal vena cava, while in the cranial region of the abdomen, it is in the median sagittal plane, being slightly displaced to the left (MILLER et al., 1964; EVANS, 1993; GETTY, 2008; DYCE et al., 2010).

In the hoary fox, the first branch originated from the abdominal aorta was the celiac artery, divided into four branches; this condition corroborates with data compiled from pertinent literature, suggesting that this is a normal condition in canids (MILLER et al., 1964; EVANS, 1993; GETTY, 2008; DYCE et al., 2010).

Similarly to dogs, we verified a pair of phrenicabdominal arteries as the second branch of the abdominal aorta, but in these animals, the phrenic-abdominal arteries may originate alone or from a common trunk (MILLER et al., 1964; EVANS, 1993; GETTY, 2008; DYCE et al., 2010).

In hoary the fox, the adrenal arteries originate from a common trunk with the phrenic-abdominal arteries, but relevant literature on dogs (MILLER et al., 1964; EVANS, 1993; GETTY, 2008; DYCE et al., 2010) reports that the origin of this vessel is very variable, and may occur alone from the abdominal aorta, between themselves in a common trunk or with other vessels, such as the renal and the cranial mesenteric arteries or the celiac artery.

Similarly to the hoary fox, the cranial mesenteric artery of dogs is the major branch of the abdominal aorta, being responsible for the blood supply of the whole small intestine and most of the large intestine (MILLER et al., 1964; EVANS, 1993; GETTY, 2008; DYCE et al., 2010). Its origin and distribution corroborates with the relevant literature on dogs.

The anatomical characteristics of renal and testicular arteries, the caudal mesenteric artery, and the deep iliac circumflex arteries, in the hoary fox agree with the compiled literature on dogs (MILLER et al., 1964; EVANS,
1993; GETTY, 2008; DYCE et al., 2010), except for the two small mesenteric arteries found in the hoary fox.

We found five pairs of lumbar arteries in the hoary fox, a smaller number compared to dogs, which have seven lumbar paired arteries. In dogs, the first two pairs originate inside the thoracic cavity and the five remaining ones originate along the abdominal segment from the aorta artery (MILLER et al., 1964; EVANS, 1993; GETTY, 2008; DYCE et al., 2010). The authors report that the lumbar arteries may originate alone or by forming a trunk, differently from that shown for the hoary fox, whose lumbar arteries originated directly from the abdominal aorta without forming trunks.

Similar to that observed among dogs, the largest branches of the final segment of the abdominal aorta in hoary fox are the external iliac arteries, which become the femoral artery in the tights (MILLER et al., 1964; EVANS, 1993; GETTY, 2008; DYCE et al., 2010).

Regarding the terminal branches of the abdominal aorta in the hoary fox, the findings differ from those found for other canids that show the internal iliac artery and the median sacral artery, without mentioning the obturator artery (MILLER et al., 1964; EVANS, 1993; GETTY, 2008; DYCE et al., 2010).

\section{Conclusion}

Considering the findings of this study, we conclude the anatomy of the abdominal part of the aorta of the hoary fox is very similar to that of domestic canids, despite the hoary fox being a wild animal. Main differences regard the origin of some branches, which are individually made and not in trunks, or also the number of vessels.

\section{Acknowledgements}

The authors thank the Institutional Voluntary Program of Scientific Initiation (PIVIC) from the Federal University of Goiás for supporting this research.

\section{Conflict of interest}

All authors declare there were no conflicts of interest.

\section{References}

DALPONTE, J. C. Lycalopex vetulus (Carnívora: Canidae). Mammalian Species, v. 847, p. 1-7, 2009. doi: $10.1644 / 847.1$
DE PAULA-COUTO, C. Memórias sobre a paleontologia brasileira. Rio de Janeiro: Ministério de Educação e Saúde; Instituto Nacional do Livro, 1950. 
DYCE, K. M.; SACK, W. O.; WENSING, C. J. G. Tratado de anatomia veterinária. 4. ed. Rio de Janeiro: Elsevier, 2010.

EVANS, H. E. The heart and the arteries. In: Miller's Anatomy of the dog. 3. ed. Philadelphya: Saunders, 1993. p. 586-681.

GETTY, R. Sisson e Grossman: anatomia dos animais domésticos. 5. ed. Rio de Janeiro: Guanabara Koogan, 2008. v. 1.

INTERNATIONAL COMMITTEE ON VETERINARY GROSS ANATOMICAL NOMENCLATURE (ICVGAN). Nomina anatomica veterinaria. 6. ed. Knoxville: World Association on Veterinary Anatomists, 2017.

LEMOS, F. G.; AZEVEDO, F. C.; BEISIEGEL, B. M.; JORGE, R. P. S.; DE PAULA, R. C.; RODRIGUES, F. H. G.; DE ALMEIDA RODRIGUES, L. Avaliação do risco de extinção da raposa-do-campo Lycalopex vetulus (Lund,
1842) no Brasil. Biodiversidade Brasileira, v. 3, n. 1, p. 160-171, 2013.

MACHADO, A. B. M.; DRUMMOND, G. M.; PAGLIA, A. P. Livro vermelho da fauna brasileira ameaçada de extinção. 1. ed. Brasília; Belo Horizonte: MMA; Fundação Biodiversitas, 2008.

MILLER, M. E.; CHRISTENSEN, G. C.; EVANS, H. E. Anatomy of the dog. Londres: W. B. Saunders Company, 1964.

OLIVEIRA, C.; TEIXEIRA, R. A. P.; CONCHALO, W. L. Uma abordagem contextualizada da anatomia humana e comparada. In: PRÓ-REITORIA DE GRADUAÇÃO DA UNIVERSIDADE ESTADUAL PAULISTA. Núcleos de Ensino. São Paulo: Editora Unesp, 2004. p. 291-310. Available from: http://bit.ly/2f22gA. Viewed: 20 jan. 2014.

RODRIGUES, H. Técnicas anatômicas. 3. ed. Vitória: Edson Maltez Heringer, 2005. 